\title{
Childhood Systemic Anaplastic Large Cell Lymphoma
}

National Cancer Institute

\section{Source}

National Cancer Institute. Childhood Systemic Anaplastic Large Cell Lymphoma. NCI

Thesaurus. Code C9471.

A systemic anaplastic large cell lymphoma that occurs during childhood. 